\title{
Characterization of cobalt oxides studied by FT-IR, Raman, TPR and TG-MS
}

\author{
Chih-Wei Tang ${ }^{\mathrm{a}}$, Chen-Bin Wang ${ }^{\mathrm{b}, *}$, Shu-Hua Chien ${ }^{\mathrm{c}, \mathrm{d}, * *}$ \\ a Department of Chemistry, Chinese Military Academy, Kaohsiung 83059, Taiwan, ROC \\ b Department of Applied Chemistry and Materials Science, Chung Cheng Institute of Technology, National Defense University, Tahsi, Taoyuan 33509, Taiwan, ROC \\ c Institute of Chemistry, Academia Sinica, Taipei 11529, Taiwan, ROC \\ d Department of Chemistry, National Taiwan University, Taipei 10764, Taiwan, ROC
}

\section{A R T I C L E I N F O}

\section{Article history:}

Received 20 February 2008

Received in revised form 22 April 2008

Accepted 23 April 2008

Available online 29 April 2008

\section{Keywords:}

Cobalt oxides

Thermal analysis

TG-MS

\begin{abstract}
A B S T R A C T
The as-prepared cobalt oxide (assigned as $\mathrm{CoO}_{x}$ ) was fabricated by precipitation-oxidation from aqueous cobalt nitrate solution using sodium hydroxide and oxidation with hydrogen peroxide. Another series of pure cobalt oxides was refined by the decomposition of $\mathrm{CoO}_{x}$ in a nitrogen environment at temperatures of 280,450 and $950{ }^{\circ} \mathrm{C}$ (D-280, D-450 and D-950, respectively). Phase transformation, structural properties and red-ox properties were characterized by thermogravimetry-mass spectrometry (TG-MS), X-ray diffraction (XRD), infrared spectroscopy (IR), Raman spectroscopy and temperature-programmed decomposition/reduction (TPD/TPR). Analysis of the thermal behavior on $\mathrm{CoO}_{x}$ revealed that a series of pure cobalt oxide with particle sizes of $10-20 \mathrm{~nm}$ could be obtained easily. The results demonstrated that the refined samples D-280, D-450 and D-950 were $\mathrm{CoO}(\mathrm{OH}), \mathrm{CO}_{3} \mathrm{O}_{4}$ and $\mathrm{CoO}$, respectively.
\end{abstract}

(C) 2008 Elsevier B.V. All rights reserved.

\section{Introduction}

Cobalt oxide has a wide range of applications in various industrial sectors, including in rechargeable batteries [1], as a catalyst of the abatement of $\mathrm{CO}$ [2], as a magnetic material [3] and in $\mathrm{CO}$ sensors [4]. Five species of cobalt oxide $\left[\mathrm{CoO}_{2}, \mathrm{Co}_{2} \mathrm{O}_{3}, \mathrm{CoO}(\mathrm{OH}), \mathrm{CO}_{3} \mathrm{O}_{4}\right.$ and $\mathrm{CoO}$ ] have been reported [4-9]. However, cobalt oxide with a valence of more than three is unstable in the natural environment. Other cobalt oxides $\left[\mathrm{CO}_{3} \mathrm{O}_{4}\right.$ and $\left.\mathrm{CoO}\right]$ are more stable and useful in industry. Cobalt oxyhydroxide, $\mathrm{CoO}(\mathrm{OH})$, has a hexagonal structure in which a divalent metal cation is located at an octahedral site which is coordinated by six hydroxyl oxygen. Well-spread $\mathrm{CoO}(\mathrm{OH})$ can be used as the conductive network in rechargeable alkaline batteries [5]. $\mathrm{CoO}$ is an antiferromagnetic material whose magnetic characteristics $[10,11]$ and application of gas-sensors $[12,13]$ have been extensively studied. $\mathrm{CoO}$ nanocomposite film in gas-sensing. $\mathrm{Co}_{3} \mathrm{O}_{4}$ exhibited high catalytic activity in $\mathrm{CO}$ oxidation [14-16]. The spinel tricobalt tetraoxide, $\mathrm{CO}_{3} \mathrm{O}_{4}$, has an energy band-gap of $1.4-1.8 \mathrm{eV}$ [17] that can be used as a p-type semiconductor and an antiferromagnetic material $[18,19]$. The distribution of cations on spinel $\mathrm{Co}_{3} \mathrm{O}_{4}$ is shown to be $\mathrm{Co}^{2+}\left[\mathrm{Co}_{2}{ }^{3+}\right] \mathrm{O}_{4}{ }^{2-}$ : the cations inside parentheses are octahedral and those outside are tetrahe-

\footnotetext{
* Corresponding author.

** Corresponding author at: Institute of Chemistry, Academia Sinica, Taipei 11529, Taiwan, ROC.

E-mail addresses: chenbinwang@gmail.com (C.-B. Wang), chiensh@gate.sinica.edu.tw (S.-H. Chien).
}

drally coordinated with oxygen ions. The complex is stable up to $800^{\circ} \mathrm{C}$ and decomposes to $\mathrm{CoO}[14,20,21]$ above $900^{\circ} \mathrm{C}$.

A preview paper [9] reported that variation in the morphology of cobalt oxides with calcination and reduction pretreatments. Figlarz et al. found that the hexagonal $\mathrm{Co}_{3} \mathrm{O}_{4}$ was obtained by the decomposition of $\mathrm{CoO}(\mathrm{OH})$ at approximately $250^{\circ} \mathrm{C}$, based on analysis by X-ray diffraction (XRD) and selected-area electron diffraction (SAED). To understand the phase transformation and the composition of decomposed outlet gases, this work discusses the analysis of the thermogravimetry-mass spectrometry (TG-MS). Temperature-programmed decomposition (TPD), X-ray diffraction (XRD), infrared spectroscopy (IR), Raman spectroscopy and temperature- programmed reduction (TPR) are employed to characterize a series of cobalt oxides.

\section{Experimental}

\subsection{Preparation of cobalt oxides}

The as-prepared cobalt oxide (assigned as $\mathrm{CoO}_{x}$ ) with a high valence state of cobalt was synthesized by the precipitationoxidation method in an aqueous solution. The precipitation process was carried out at $50{ }^{\circ} \mathrm{C}$ with $50 \mathrm{ml}$ of $0.6 \mathrm{M} \mathrm{Co}\left(\mathrm{NO}_{3}\right)_{2} \cdot \mathrm{H}_{2} \mathrm{O}$ solution added drop by drop to $100 \mathrm{ml}$ of $3.2 \mathrm{M} \mathrm{NaOH}$ solution; $100 \mathrm{ml}$ of $\mathrm{H}_{2} \mathrm{O}_{2}$ (50 wt\%) was then introduced dropwisely under constant stirring. In order to avoid the contamination of chloride ion, the $\mathrm{H}_{2} \mathrm{O}_{2}$ was chosen as an oxidizing agent instead of $\mathrm{NaOCl}$ [22]. The precipitate was then filtered, washed with deionized water and dried in 
an oven at $110{ }^{\circ} \mathrm{C}$ for $24 \mathrm{~h}$. The dried $\mathrm{CoO}_{x}$ was ground and preserved in a desiccator as fresh samples. Further, other series of pure cobalt oxide were refined from the decomposition of $\mathrm{CoO}_{x}$ under nitrogen environment at different temperatures: 280,450 and $950{ }^{\circ} \mathrm{C}$, respectively (assigned as D-280, D-450 and D-950, respectively).

\subsection{Characterization techniques}

X-ray diffraction (XRD) measurements were performed using a Siemens D5000 diffractometer with $\mathrm{Cu} K \alpha 1$ radiation $(\lambda=1.5405 \AA)$ at $40 \mathrm{kV}$ and $30 \mathrm{~mA}$ with a scanning speed in $2 \theta$ of $2^{\circ} \mathrm{min}^{-1}$. Using the XRD diffraction data, the crystallite sizes of cobalt oxides were able to be estimated using the Scherrer equation.

$d=\frac{0.9 \lambda}{B \cos \theta_{\mathrm{B}}}$

In this equation, $d$ is the crystallite size $(\mathrm{nm}) ; \lambda$ the X-ray wavelength; $B$ the full width at half maximum of the diffraction peak at $\theta_{\mathrm{B}} ; \theta_{\mathrm{B}}$ is the diffraction angle.

Specific surface area measurements were carried out by using the Brunauer-Emmett-Teller (BET) method on a Micromeritics ASAP 2010 apparatus. Nitrogen adsorption isotherms at $-196^{\circ} \mathrm{C}$ were determined volumetrically. The catalysts were pre-outgassed at $5 \times 10^{-5}$ Torr for $3 \mathrm{~h}$ at $110^{\circ} \mathrm{C}$. The surface area was determined from the nitrogen adsorption isotherm.

IR spectra of samples were obtained by a Bomen DA-8 spectrometer with a resolution of $4 \mathrm{~cm}^{-1}$ in the range of $450-1000 \mathrm{~cm}^{-1}$. One milligram of each powder sample was diluted with $200 \mathrm{mg}$ of vacuum-dried IR-grade $\mathrm{KBr}$ powder and subjected to a pressure of 10 tons. The measurements of Raman spectroscopy were recorded using a Nicolet Almega XR dispersive Raman spectrometer. The spectra were collected between 300 and $900 \mathrm{~cm}^{-1}$, using a beam of diode laser $(780 \mathrm{~nm})$, with the sample exposed to the air under ambient conditions.

TPR of a series of cobalt oxides was performed using $10 \% \mathrm{H}_{2}$ in $\mathrm{Ar}$ as the reducing gas. The flow rate of $\mathrm{H}_{2} / \mathrm{Ar}$ was adjusted by mass flow controller under $25 \mathrm{ml} \mathrm{min}^{-1}$. The cell was a quartz tube with an inner diameter $8 \mathrm{~mm}$ and $80 \mathrm{mg}$ of the catalyst was mounted with quartz wool. The hydrogen consumption was monitored by a thermal conductivity detector (TCD) on raising the sample temperature from RT to $500^{\circ} \mathrm{C}$ at a constant rate of $5^{\circ} \mathrm{C} \mathrm{min}^{-1}$. TPD profile of $\mathrm{CoO}_{x}$ sample was performed using $\mathrm{He}$ as carrier gas. The flow rate of He was adjusted to $25 \mathrm{ml} \mathrm{min}^{-1}$. The oxygen desorption was monitored by a TCD on raising the sample temperature from RT to $1000^{\circ} \mathrm{C}$ at a constant rate of $10^{\circ} \mathrm{C} \mathrm{min}-1$.

On-line TG-MS analyses of the gases evolved from the sample were performed simultaneously using the STA-409CD with Skimmer coupled to a quadruple mass spectrometer QMA 400 (maximum $512 \mathrm{amu}$ ). The TG experiments were operated from RT to $1100{ }^{\circ} \mathrm{C}$ with heating rate of $10^{\circ} \mathrm{C} \mathrm{min}^{-1}$ under a continuous flow of $\mathrm{He}\left(100 \mathrm{ml} \mathrm{min}^{-1}\right)$. A transfer line, specially designed to connect a vacuum pump in order to optimize the amount of evolved gas, transferred from the TG to the MS. A mass analysis was performed each $2 \mathrm{~s}$ recording mass fragments between 2 and 300 atomic mass

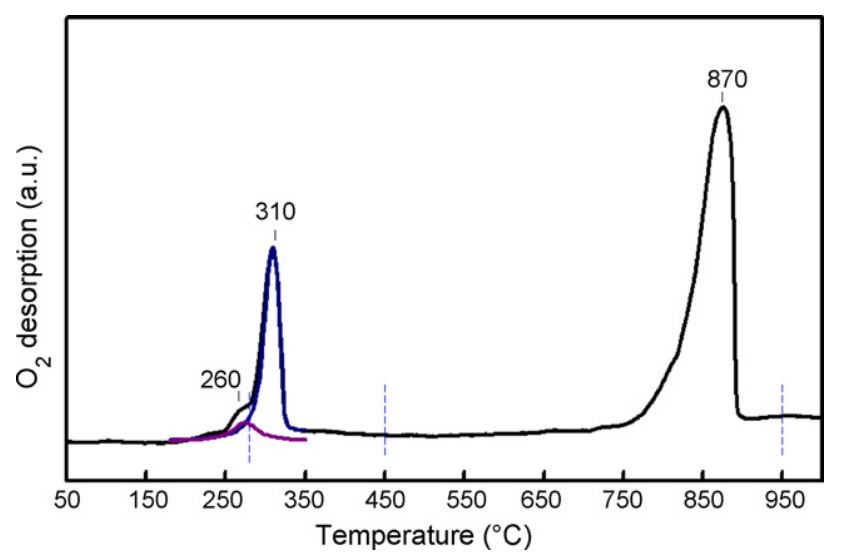

Fig. 1. TPD profile of $\mathrm{CoO}_{x}$.

units (amu). The measurement of outlet gas via mass spectrometric intensities was plotted as a function of temperature that showed two well separated regions of de-volatilization.

\section{Results and discussion}

\subsection{Structural analysis of cobalt oxides}

Fig. 1 displays the TPD profile of the as-prepared $\mathrm{CoO}_{x}$ sample. Three peaks of oxygen desorption at different temperatures $\left(T_{\mathrm{d}}\right)-D_{1}\left(T_{\mathrm{d}}=260^{\circ} \mathrm{C}\right), D_{2}\left(T_{\mathrm{d}}=310^{\circ} \mathrm{C}\right)$ and $D_{3}\left(T_{\mathrm{d}}=870^{\circ} \mathrm{C}\right)-$ are observed. The sequential desorption of oxygen from $\mathrm{CoO}_{x}$ indicates that cobalt oxide with different oxidation states may be obtained by the appropriate thermal decomposition of $\mathrm{CoO}_{x}$ in a nitrogen environment.

$$
\mathrm{CoO}_{x} \stackrel{D_{1}}{\longrightarrow} \mathrm{CoO}(\mathrm{OH}) \stackrel{D_{2}}{\longrightarrow} \mathrm{Co}_{3} \mathrm{O}_{4} \stackrel{D_{3}}{\longrightarrow} \mathrm{CoO}
$$

Cobalt ions with an oxidation state of $+3[\mathrm{CoO}(\mathrm{OH})],+8 / 3$ $\left[\mathrm{Co}_{3} \mathrm{O}_{4}\right]$ and $+2[\mathrm{CoO}]$ may be obtained from $\mathrm{CoO}_{x}$ by thermal decomposition at 280,450 and $950^{\circ} \mathrm{C}$, respectively. Samples prepared in this way are designated herein as D-280, D-450 and D-950. Although $D_{1}$ and $D_{2}$ peaks in the spectrum are merged together, the desired pure sample of $\mathrm{CoO}(\mathrm{OH})$ is easily obtained by the simple thermal decomposition of $\mathrm{CoO}_{x}$ at $280^{\circ} \mathrm{C}$ in the TPD system (see the characterizations below).

Fig. 2 shows XRD patterns of refined species of cobalt oxide. Columns 2-4 of Table 1 presents the species, crystal phase and particle size of theses oxides. The diffraction profile of the D-280 sample (Fig. 2(a)) matches the JCPDS (PDF-74-1057) [23] file, identifying cobalt oxyhydroxide, $\mathrm{CoO}(\mathrm{OH})$, with a hexagonal structure. The average particle size is small $(10 \mathrm{~nm}$, according to the peak width and the Scherrer equation). The D-450 sample (Fig. 2(b)) matches the JCPDS (PDF-76-1802) file identifying cobaltic oxide, $\mathrm{Co}_{3} \mathrm{O}_{4}$, with a spinel structure. The D-950 sample (Fig. 2(c)) matches the JCPDS (PDF-71-1178) file for cobaltous oxide, CoO, with a facecentered cubic (fcc) structure. The peak width in the D-950 pattern

Table 1

A series of the species of cobalt oxide for characterization

\begin{tabular}{|c|c|c|c|c|c|c|c|c|}
\hline \multirow[t]{2}{*}{ Samples } & \multicolumn{2}{|l|}{ XRD } & \multirow[t]{2}{*}{$S_{\text {BET }}$} & \multirow{2}{*}{$\begin{array}{l}\text { FT-IR }\left(\mathrm{m}^{2} \mathrm{~g}^{-1}\right) \\
v_{\mathrm{Co}-\mathrm{O}}\left(\mathrm{cm}^{-1}\right)\end{array}$} & \multirow[t]{2}{*}{ Raman shift $\left(\mathrm{cm}^{-1}\right)$} & \multicolumn{3}{|l|}{ TPR (C) } \\
\hline & Structure ${ }^{\mathrm{a}}$ & $d(\mathrm{~nm})^{\mathrm{b}}$ & & & & $\mathrm{CO}_{3} \mathrm{O}_{4}$ & $\mathrm{CoO}$ & Co \\
\hline $\mathrm{CoOOH}$ & Hexagonal & 10 & 59 & 584 & $367,482,599,809$ & 240 & 295 & 500 \\
\hline $\mathrm{Co}_{3} \mathrm{O}_{4}$ & Spinel & 11 & 55 & 570,661 & $482,519,621,690$ & - & 340 & 500 \\
\hline $\mathrm{CoO}$ & fcc & 16 & 5 & 507 & 455,675 & - & - & 550 \\
\hline
\end{tabular}

a According to the data base of JCPDS2001.

b Particle size by Debye-Scherrer equation with $\mathrm{CoOOH}(111), \mathrm{Co}_{3} \mathrm{O}_{4}(311)$ and $\mathrm{CoO}(200)$ peak. 


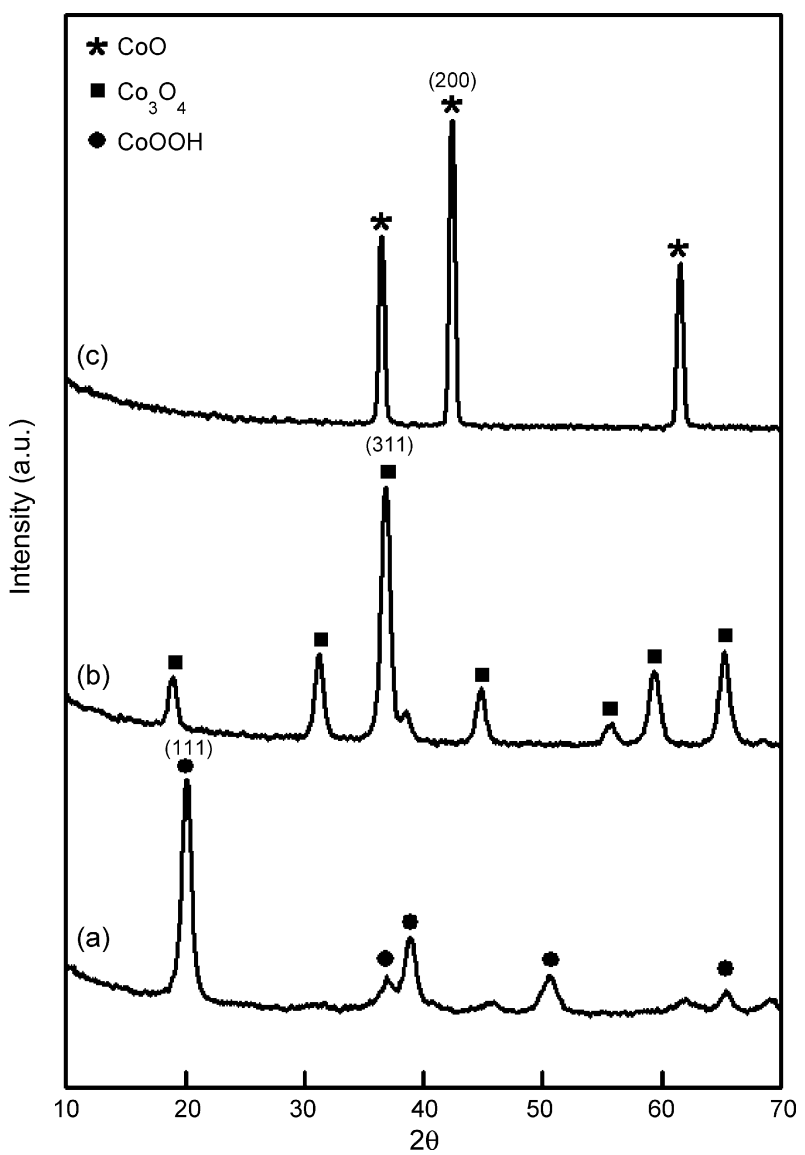

Fig. 2. XRD profiles of (a) D-280 (b) D-450 (c) D-950.

indicates substantial sintering of primary crystallites ( $d$ increases to $16 \mathrm{~nm}$ ). Nitrogen adsorption isotherms on a series of cobalt oxides are obtained at $-196^{\circ} \mathrm{C}$. They are similar across the adsorbents of interest. They are type II by Brunauer's classification. The decrease in the surface area (column 5 in Table 1) is associated with the sintering of D-950 sample.

The phase transformation revealed by XRD is accompanied by simultaneous variation in both IR and Raman spectra. Fig. 3 shows the IR absorption spectra of D-280, D-450 and D-950 samples. The IR spectra of D-280 and D-950 samples (Fig. 3(a) and (c)) display single bands ( 584 and $507 \mathrm{~cm}^{-1}$ ) that are likely to be associated with the cobalt ion in octahedral holes, meaning in an oxygen octahedral environment [24].

The variation may be caused by the difference between their structures (hexagonal vs. face-centered cubic). The IR spectrum of D-450 sample (Fig. 3(b)) displays two distinct bands that originate from the stretching vibrations of the metal-oxygen bonds $[22,23,25]$. The first band $\left(v_{1}\right)$ at $570 \mathrm{~cm}^{-1}$ is associated with the $\mathrm{OB}_{3}$ vibration in the spinel lattice, where $\mathrm{B}$ denotes $\mathrm{Co}^{3+}$ in an octahedral hole. The second band $\left(v_{2}\right)$ at $661 \mathrm{~cm}^{-1}$ is attributed to the $\mathrm{ABO}_{3}$ vibration, where $\mathrm{A}$ denotes the $\mathrm{Co}^{2+}$ in a tetrahedral hole.

Fig. 4 displays the Raman spectra of a series of the cobalt oxides formed by thermal decomposition. The D-280 sample has bands at $367,482,599$ and $809 \mathrm{~cm}^{-1}$ (Fig. 4(a)), which are assigned to $\mathrm{CoO}(\mathrm{OH})$. Following the higher-temperature treatments, different bands were observed at $482,519,621,690 \mathrm{~cm}^{-1}$ for D-450 (Fig. 4(b)) and $455,675 \mathrm{~cm}^{-1}$ for D-950 (Fig. 4(c)), probably because of the phase transformation under heat treatment. The prominent Raman peaks correspond to the $E_{\mathrm{g}}\left(482 \mathrm{~cm}^{-1}\right), F_{2 \mathrm{~g}}\left(519\right.$ and $\left.621 \mathrm{~cm}^{-1}\right), A_{1 \mathrm{~g}}$ $\left(690 \mathrm{~cm}^{-1}\right)$ modes of the $\mathrm{CO}_{3} \mathrm{O}_{4}$ crystalline phase (D-450) and are

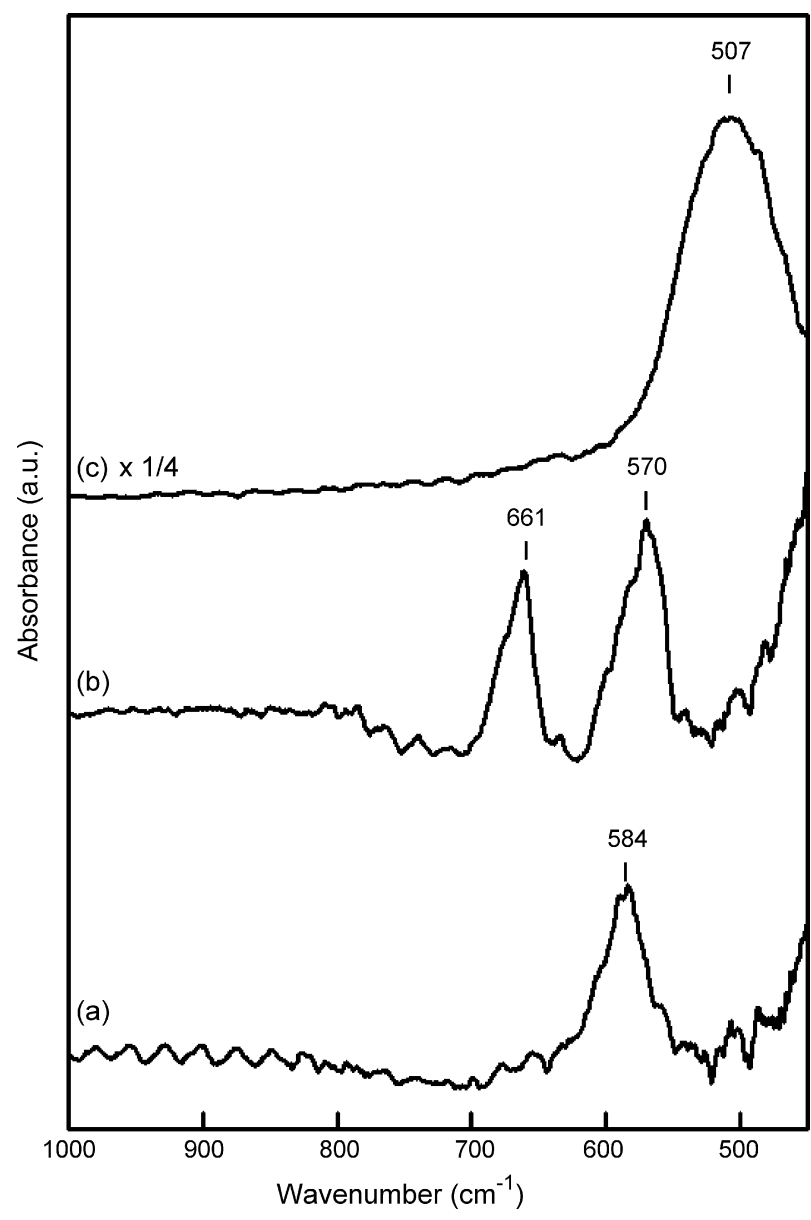

Fig. 3. FTIR spectra of (a) D- 280 (b) D- 450 (c) D-950.

consistent previous investigations [26,27]. Upon heat treatment at $950{ }^{\circ} \mathrm{C}$, the 519 and $621 \mathrm{~cm}^{-1}$ peak disappeared and broad bands at 455 and $675 \mathrm{~cm}^{-1}$ appeared, because of the formation of cubic $\mathrm{CoO}$. These are shifted from the positions of the main peaks, 672 and $468 \mathrm{~cm}^{-1}$, in previous studies of bulk $\mathrm{CoO}$ [28-30], shifted because of the nano-sized effect. This result confirms that the crystalline structure of the series of cobalt oxides can be identified by Raman spectroscopy.

\subsection{Reductive behavior of cobalt oxides}

Fig. 5 compares the reduction behavior of the series of cobalt oxides. The D-280 sample (Fig. 5(a)) yields three sequent signals at 215,260 and $350^{\circ} \mathrm{C}$. According to our previous study [2], we have stopped each TPR step (under three reduction temperature) to record the XRD pattern of the sample and then to have a definitive knowledge of the phase formed after each reduction peak (from $\mathrm{CoO}(\mathrm{OH})$ to $\mathrm{Co} 3 \mathrm{O} 4$, then to $\mathrm{CoO})$. So, we suggests that the $\mathrm{CoO}(\mathrm{OH})$ (D-280) is initially reduced to $\mathrm{Co}_{3} \mathrm{O}_{4}$, and then further reduced to $\mathrm{CoO}$ and $\mathrm{Co}$ metal. The following equations are designated.

$$
\begin{aligned}
& 6 \mathrm{CoO}(\mathrm{OH})+\mathrm{H}_{2} \rightarrow 2 \mathrm{Co}_{3} \mathrm{O}_{4}+4 \mathrm{H}_{2} \mathrm{O} \\
& \mathrm{Co}_{3} \mathrm{O}_{4}+\mathrm{H}_{2} \rightarrow 3 \mathrm{CoO}+\mathrm{H}_{2} \mathrm{O} \\
& \mathrm{CoO}+\mathrm{H}_{2} \rightarrow \mathrm{Co}+\mathrm{H}_{2} \mathrm{O}
\end{aligned}
$$

Fig. 5(b) shows the TPR profile of D-450 sample; it includes only two reductive singles at 300 and $367{ }^{\circ} \mathrm{C}$. Sexton et al. [31] found that the reduction profile of $\mathrm{Co}_{3} \mathrm{O}_{4}$ includes a low-temperature peak below $300^{\circ} \mathrm{C}$ and a high-temperature peak at approximately 


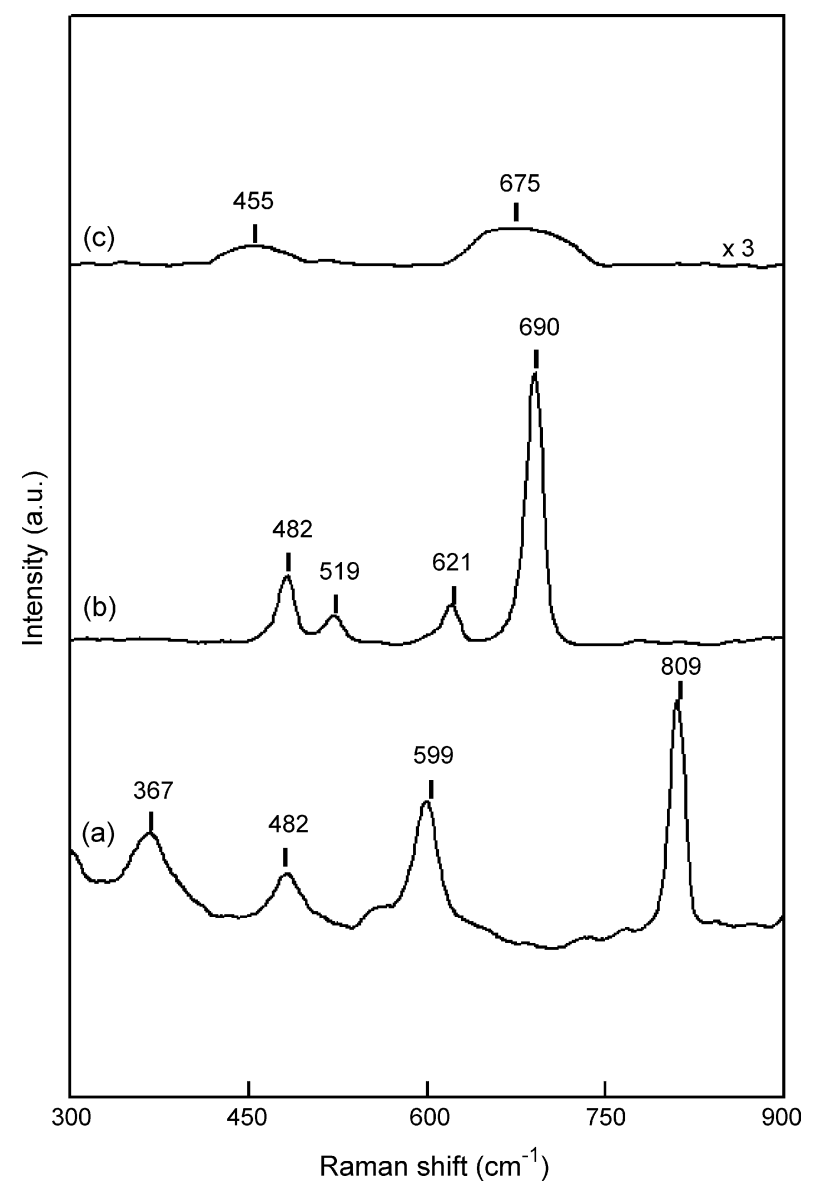

Fig. 4. Raman spectra of (a) D-280 (b) D-450 (c) D-950.

$500{ }^{\circ} \mathrm{C}$. According to the literature [32-35], the low-temperature peak is associated with the reduction of $\mathrm{Co}^{3+}$ ions to $\mathrm{Co}^{2+}$ (Eq. (4)) with the subsequent structural change to $\mathrm{CoO}$. The second higher temperature peak is due to the reduction of $\mathrm{CoO}$ to metallic cobalt (Eq. (5)). A comparison with the D-280 sample, and in particular, the disappearance of the peak at around the lowest temperature indicates that the reductive behavior is in good agreement with the proposed $\mathrm{Co}_{3} \mathrm{O}_{4}$. The TPR profile of the D-950 sample (Fig. 5(c)) includes only a single peak, which is assigned unambiguously to the direct reduction of $\mathrm{CoO}$ to cobalt metal.

\subsection{Analysis of evolved gas of cobalt oxides}

To confirm the phase transformation of $\mathrm{CoO}(\mathrm{OH})$ to $\mathrm{Co}_{3} \mathrm{O}_{4}$ and $\mathrm{CoO}$ under heat treatment, coupled quantitative and qualitative analysis by TG-MS was performed to prove the structural identifications in Section 3.1. Fig. 6 presents the TG-MS profile of the D-280 sample. The thermogravimetric plot presents two marked weight losses at about 280 and $850^{\circ} \mathrm{C}$. Column 4 in Table 2 shows that these are $12 \%$ and $20 \%$, respectively. The coupled TG-MS analysis reveals that the evolved gases are oxygen $\left(\mathrm{O}_{2}, \mathrm{~m} / \mathrm{z}=32\right)$ and steam $\left(\mathrm{H}_{2} \mathrm{O}\right.$, $m / z=18$ ). The red curve assigned to $\mathrm{O}_{2}$ has a small first peak and a large second peak. The blue curve assigned to $\mathrm{H}_{2} \mathrm{O}$ is related to the crystal structure. Comparing the theoretical weight loss of the proposed reactions (columns 2 and 3 in Table 2 ) with the experimental results demonstrates the simultaneous desorption of $\mathrm{O}_{2}$ and $\mathrm{H}_{2} \mathrm{O}$ from $\mathrm{CoO}(\mathrm{OH})$ into $\mathrm{Co}_{3} \mathrm{O}_{4}$ at around $280^{\circ} \mathrm{C}$.

The second weight loss, confirmed by MS analysis, shows the decomposition of $\mathrm{Co}_{3} \mathrm{O}_{4}$ to $\mathrm{CoO}$ at around $850^{\circ} \mathrm{C}$. Therefore, the

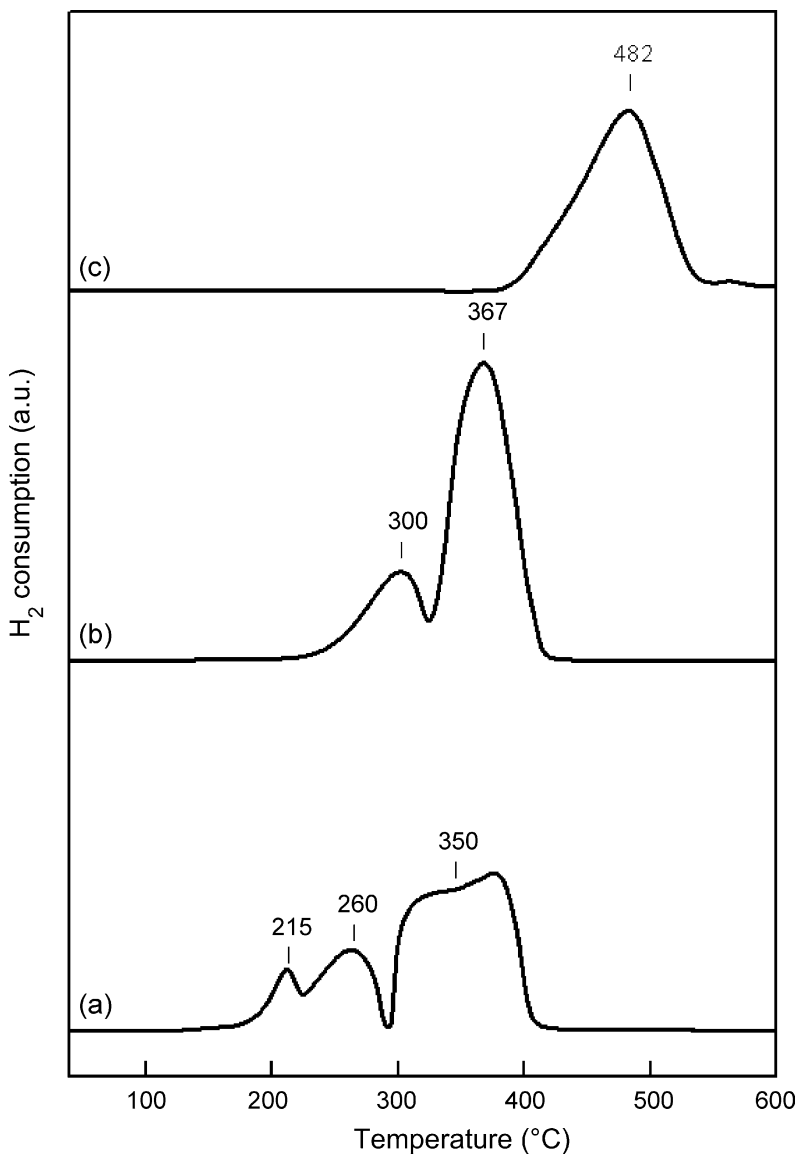

Fig. 5. TPR profiles of (a) D-280 (b) D-450 (c) D-950.

D-280 sample can be decomposed into $\mathrm{Co}_{3} \mathrm{O}_{4}$ and then $\mathrm{CoO}$ under heat treatment.

$12 \mathrm{CoO}(\mathrm{OH}) \rightarrow 4 \mathrm{Co}_{3} \mathrm{O}_{4}+\mathrm{O}_{2}+6 \mathrm{H}_{2} \mathrm{O}$

$2 \mathrm{Co}_{3} \mathrm{O}_{4} \rightarrow 6 \mathrm{CoO}+\mathrm{O}_{2}$

Fig. 7 shows the TG-MS profile of the D-450 sample. At under $300^{\circ} \mathrm{C}$, the tardy weight loss is associated with desorption of adsorbed water on the surface of $\mathrm{Co}_{3} \mathrm{O}_{4}$. The red curve is assigned

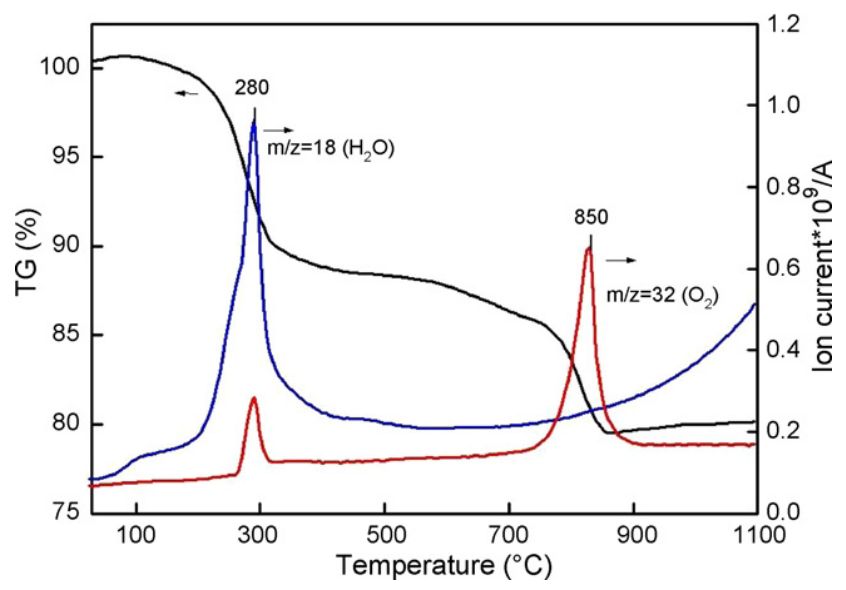

Fig. 6. Analysis of the outlet gases from the decomposition of D-280 by TG-MS (heating rate of $10{ }^{\circ} \mathrm{Cmin}^{-1}$ under $\mathrm{He}$ ): $\mathrm{H}_{2} \mathrm{O}$ (blue) and $\mathrm{O}_{2}$ (red). (For interpretation of the references to color in this figure legend, the reader is referred to the web version of the article.) 
Table 2

Experimental and theorization of a series of cobalt oxide for TG-MS

\begin{tabular}{|c|c|c|c|c|c|}
\hline \multirow[t]{2}{*}{ Sample } & \multirow[t]{2}{*}{ Reaction process } & \multicolumn{2}{|c|}{ Weight loss $(\%)^{\mathrm{a}}$} & \multicolumn{2}{|c|}{ Outlet gas $(\mathrm{C})^{\mathrm{b}}$} \\
\hline & & Theoretical & Experimental & $\mathrm{H}_{2} \mathrm{O}$ & $\mathrm{O}_{2}$ \\
\hline $\mathrm{CoOOH}^{\mathrm{c}}$ & $\begin{array}{l}12 \mathrm{CoO}(\mathrm{OH}) \rightarrow 4 \mathrm{Co}_{3} \mathrm{O}_{4}+\mathrm{O}_{2}+6 \mathrm{H}_{2} \mathrm{O} \\
2 \mathrm{Co}_{3} \mathrm{O}_{4} \rightarrow 6 \mathrm{CoO}+\mathrm{O}_{2}\end{array}$ & $\begin{array}{l}13 \\
19\end{array}$ & $\begin{array}{l}12 \\
20\end{array}$ & 300 & 920 \\
\hline $\mathrm{CO}_{3} \mathrm{O}_{4}{ }^{\mathrm{c}}$ & $2 \mathrm{Co}_{3} \mathrm{O}_{4} \rightarrow 6 \mathrm{CoO}+\mathrm{O}_{2}$ & 7 & 8 & - & 820 \\
\hline $\mathrm{CoO}^{\mathrm{d}}$ & $6 \mathrm{CoO}+\mathrm{O}_{2} \stackrel{A}{\longrightarrow} 2 \mathrm{Co}_{3} \mathrm{O}_{4} \stackrel{B}{\longrightarrow} 6 \mathrm{CoO}+\mathrm{O}_{2}$ & $\begin{array}{l}\text { A:7 } \\
\text { B:-7 }\end{array}$ & $\begin{array}{l}A: 7 \\
B:-8\end{array}$ & - & 920 \\
\hline
\end{tabular}

a Measurement of TG.

b Measurement of mass analyzer.

c By TG-MS flow He.

d By TG-MS flow air.

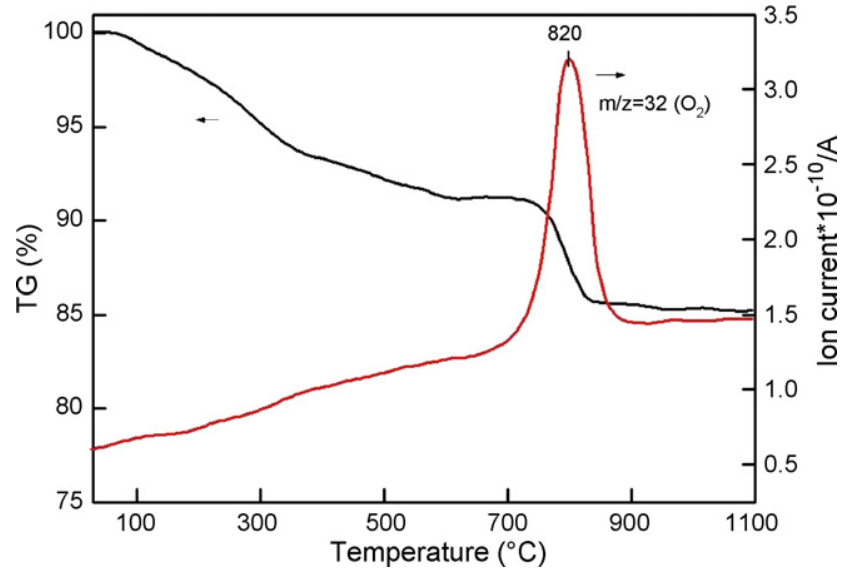

Fig. 7. Analysis of the outlet gases from the decomposition of D-450 by TG-MS (heating rate of $10^{\circ} \mathrm{C} \mathrm{min}^{-1}$ under $\mathrm{He}$ ): $\mathrm{O}_{2}$ (red). (For interpretation of the references to color in this figure legend, the reader is referred to the web version of the article.)

to $\mathrm{O}_{2}$ at $820^{\circ} \mathrm{C}$. The weight loss of $8 \%$ is caused mainly by the decomposition of $\mathrm{Co}_{3} \mathrm{O}_{4}$ to $\mathrm{CoO}$, according to Eq. (7).

Fig. 8 shows the TG profile of the D-950 sample in air. The weight increase of $7 \%$ involves mainly the oxidation of $\mathrm{CoO}$ to $\mathrm{Co}_{3} \mathrm{O}_{4}$ as the temperature is increased from 250 to $900^{\circ} \mathrm{C}$, followed by the desorption of oxygen to $\mathrm{CoO}$ at above $900^{\circ} \mathrm{C}$. Comparing the theoretical weight variations of the proposed reaction (columns 2 and 3 in Table 2) with the experimental results demonstrated that $\mathrm{CoO}$ can undergo oxidation-reduction in air, according to Eq. (8).

$6 \mathrm{CoO}+\mathrm{O}_{2} \rightarrow 2 \mathrm{Co}_{3} \mathrm{O}_{4} \rightarrow 6 \mathrm{CoO}+\mathrm{O}_{2}$

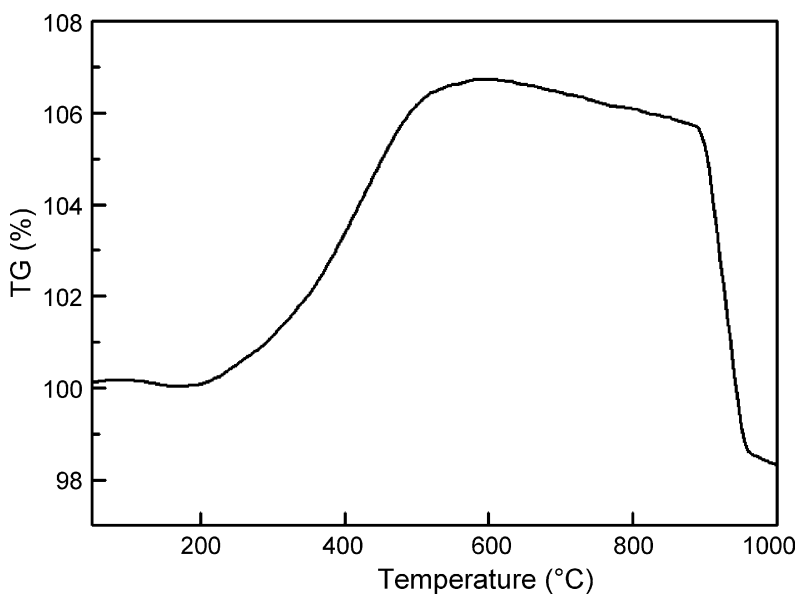

Fig. 8. TG profile of D-950 at a heating rate of $10^{\circ} \mathrm{C} \mathrm{min}^{-1}$ under air.

\section{Conclusions}

A convenient procedure for preparing a series of pure cobalt oxides is presented; it involves the decomposition of $\mathrm{CoO}_{x}$ in a nitrogen environment at different temperatures.

TG-MS, XRD, Raman, FTIR and TPR analyses are demonstrated to be useful in identifying the series of cobalt oxides. The D-280 sample $[\mathrm{CoO}(\mathrm{OH})]$ has a hexagonal structure that gives rise to $\mathrm{Co}_{3} \mathrm{O}_{4}$ and $\mathrm{CoO}$ in helium at 280 and $850^{\circ} \mathrm{C}$, respectively. The D-450 sample $\left[\mathrm{Co}_{3} \mathrm{O}_{4}\right]$ has a spinel structure that gives rise to $\mathrm{CoO}$ in helium at $820^{\circ} \mathrm{C}$. The $\mathrm{D}-950$ sample [CoO] has a faced-centered cubic structure that can be oxidized to $\mathrm{Co}_{3} \mathrm{O}_{4}$ at $200-600^{\circ} \mathrm{C}$ and decomposed to $\mathrm{CoO}$ at $850-1000^{\circ} \mathrm{C}$ in air, respectively. The preparation of materials and the analysis of their thermal behavior is a convenient way to control and determining the purity of cobalt oxide.

\section{Acknowledgements}

We are pleased to acknowledge financial supports for this study from Academia Sinica and the National Science Council of the Republic of China.

\section{References}

[1] F. Lichtenberg, K. Kleinsorgen, J. Power Sources 62 (1996) 207.

[2] H.K. Lin, H.C. Chiu, H.C. Tsai, S.H. Chien, C.B. Wang, Catal. Lett. 88 (2003) 169

[3] S.A. Makhlouf, J. Magn. Magn. Mater. 246 (2002) 184.

[4] H. Yamaura, K. Moriya, N. Miura, N. Yamazoe, Sens. Actuators B 65 (2000) 39.

[5] R. Van Zee, Y. Hamrick, S. Li, W. Weltner, J. Phys. Chem. 96 (1992) 7247.

[6] Comprehensive Inorganic Chemistry, vol. 3, Pergamon Press, Oxford, 1973, p. 1107.

[7] M. Elemongy, M. Gouda, Y. Elewady, J. Electroanal. Chem. 76 (3) (1977) 367.

[8] D. Chen Yih-Wen, N.N. Rommel, J. Electrochem. Soc. 131 (4) (1984) 731.

[9] C.B. Wang, H.K. Lin, C.W. Tang, Catal. Lett. 94 (2004) 69.

[10] A. Berger, M.J. Pechan, R. Compton, J.S. Jiang, J.E. Pearson, S.D. Bader, Phys. Rev. B 306 (2001) 235.

[11] M. Rubinstein, P. Lubitz, S.F. Cheng, J. Magn. Magn. Mater. 195 (1999) 299.

[12] N. Koshizaki, K. Yasumoto, T. Sasaki, Nanostruct. Mater. 12 (1999) 971

[13] N. Koshizaki, K. Yasumoto, T. Sasaki, Sens. Actuators B 66 (2000) 122.

[14] G.A. El-Shobaky, T. El-Nabarawy, I.F. Hewaidy, Surf. Technol. 10 (1980) 225.

[15] G.A. El-Shobaky, I.F. Hewaidy, N.M. Ghoneium, Thermochim. Acta 53 (1982) 105.

[16] G.A. El-Shobaky, T. El-Nabarawy, T.M. Ghazy, Surf. Technol. 15 (1982) 153.

[17] L. Börnstein, Physics of Non-tetrahedrally Bonded Binary Compounds, 17, Springer, New York, 1984.

[18] C. Wanger, E. Kock, Z. Phys. Chem. B 31 (1936) 439.

[19] P. Kostad, Non-stoichimetry, in: Diffusion and Electrical Conductivity in Binary Metal Oxides, Wiley-Interscience, New York, 1972, p. 426.

[20] G.A. El-Shobaky, T. El-Nabarawy, I.F. Hewaidy, Surf. Technol. 10 (1980) 311

[21] M. Figlarz, J. Guenot, F. Fievent-Vincent, J. Mater. Sci. 11 (1976) 2267.

[22] S.G. Christoskova, M. Stoyanova, M. Georgieva, D. Mehandjiev, Mater. Chem. Phys. 60 (1999) 39.

[23] T. Andrushkevich, G. Boreskov, V. Popovskii, L. Pliasova, L. Karakchiev, A Ostankovitch, Kinet. Catal. 6 (1968) 1244

[24] Y. Okamoto, H. Nakano, T. Imanaka, S. Teranishi, Bull. Chem. Soc. Jpn. 48 (1975) 1163.

[25] C. Spenser, D. Schroeder, Phys. Rev. B 9 (1974) 3658.

[26] J. Llorca, P.R. Piscina, J.A. Dalmon, N. Homs, Chem. Mater. 16 (2004) 3573. 
27] V.G. Hadjiev, M.N. Iliev, I.V. Vergilov, J. Phys. C: Solid State Phys. 21 (1988) L199.

[28] H.C. Choi, Y.M. Jung, I. Noda, S.B. Kim, J. Phys. Chem. B 107 (2003) 5806.

[29] M.M. Vuurman, D.J. Stufkens, A. Oskam, G. Deo, I.E. Wachs, J. Chem. Soc., Faraday Trans. 92 (1996) 3259

[30] C.A. Melendres, S.J. Xu, J. Electrochem. Soc. 131 (1984) 2239.
[31] B.A. Sexton, A.E. Hughes, T.W. Turney, J. Catal. 97 (1986) 390.

[32] H.Y. Lin, Y.W. Chen, Mater. Chem. Phys. 85 (2004) 171.

[33] C.B. Wang, C.W. Tang, S.J. Gau, S.H. Chien, Catal. Lett. 101 (2005) 59.

[34] P. Arnoldy, J.A. Moulijn, J. Catal. 93 (1985) 38.

[35] M. Vob, D. Borgmann, G. Wedler, J. Catal. 212 (2002) 10. 